\title{
Distance Variation of Light Source Effects toward Dye- Sensitized Solar Cell (DSSC) Performance using Anthocyanin Extract from Rosella Flower
}

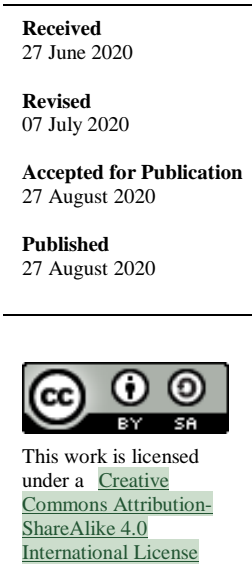

\author{
R Andari \\ Department of Electrical Engineering, Faculty of Engineering, Institut Teknologi Padang, Gajah \\ Mada Street, Kandis Nanggalo, Padang City, 25132, Indonesia.
}

Email: rafika.andari09@gmail.com

\begin{abstract}
This study aims to determine the characteristics of DSSC using rosella flower extracts with variations in the distance of the light source to DSSC. The characteristics measured are current and voltage values and cell efficiency. A 150-watt halogen lamp is used as the light source. Light source was placed at a distance of $10 \mathrm{~cm}, 20 \mathrm{~cm}$, and $30 \mathrm{~cm}$. The voltage and current value of the halogen lamp with a distance of $10 \mathrm{~cm}$ to DSSC are greater than the distance of $20 \mathrm{~cm}$ and $30 \mathrm{~cm}$. The test results show that the cell efficiency of $10 \mathrm{~cm}$ to DSSC is the most maximum with current $\left(I_{\max }\right)$ of $0.08 \mathrm{~mA}$, maximum voltage $\left(V_{\max }\right)$ of $306.7 \mathrm{mV}$ and the efficiency of $0.046 \%$. The smaller the distance of the halogen lamp to DSSC increases the intensity of the light so that the greater the DSSC output value.

Keywords: DSSC, solar cell, anthocyanin, rosella.
\end{abstract}

\section{Introduction}

Solar energy belongs to one of the renewable energy that carries various benefits for humankind. One of those benefits is the solar cell. The solar cell works by directly transforming solar energy into electrical energy. Currently, solar cell technology mostly uses silicon-based conductor material. However, the application of silicon solar cells is still classified as high-priced and involved dangerous chemical substances in its making process. Therefore, the development of alternative solar cell with affordable and environmentally friendly fundamental material is required, such as DSSC (DyeSensitized Solar Cell). The development of DSSC comprises of uncomplicated process, economical price, and basic organic material [1], [2].

A dye-sensitized solar cell (DSSC) was firstly suggested by Michael Gratzel and O'regan in 1991 [3]. Generally, it subsists of photoanode, dye as a photosensitizer, redox electrolytes, and the opposing electrodes [4]. DSSC uses metal oxides, such as $\mathrm{ZnO}$ [5], $\mathrm{SnO}_{2}$ [6], and $\mathrm{TiO}_{2}$ [7], as photoanode. However, practically, $\mathrm{TiO}_{2}$ is the most used photoanode since it carries faster interfacial recombination of an electron than $\mathrm{ZnO}$ and $\mathrm{SnO}_{2}$ [8]. Recently, the development of DSSC using dye from the plant's anthocyanins extract has been carried out with $\mathrm{TiO}_{2}$ as the photoanode, such as using the dragon fruit extract with the efficiency of $0,22 \%$ [9], carrot extract with the efficiency of $0,00124 \%$ [10], spinach leaf's extract [11], and the extract of rosella flower (Hibiscus sabdariffa l.) has proven to have the natural dye-sensitized ability due to its photovoltaic effect [12]. The related previous studies also demonstrate the excellent performance of rosella's extract as dye sensitizer [13]-[16].

This study employs the flower petals of rosella (Hibiscus sabdariffa) as the dye source. Rosella flower is one of the organic material for dye source since it has anthocyanin compounds. Besides, this flower also has an attractive red color and unique flavor. This flower is also known as a functional food due to the high antioxidant from its huge anthocyanins [17]. Further, this study investigates the variation of light source effects on the DSSC performance. 


\section{Method}

\subsection{Production of $\mathrm{TiO}_{2}$ Paste}

The preparation of $\mathrm{TiO}_{2}$ paste was completed using a thick-film technique by blending 3,07 grams of polyvinyl alcohol (PVA) to $30 \mathrm{ml}$ of aquades and stirring it for 30 minutes at $40{ }^{\circ} \mathrm{C}$ using a magnetic stirrer. Then, 3.10 gram of $\mathrm{TiO}_{2}$ was added until the paste was formulated. The paste viscosity was adjusted from the amount of binding compound used.

\subsection{Dye Extraction from Rosella Flower Extract}

The 1.5 gram of rosella flower was soaked in the mixture of methanol, acetic acid, and water with a ratio of 25:4:21. The volume of the solution was $10 \mathrm{ml}$. after that, it was macerated for 24 hours and filtered using filter paper [18].

\subsection{Creation of Electrolyte Solution}

The 0.8 gram of potassium iodide (KI) was dissolved into $10 \mathrm{ml}$ of acetonitrile. It was then stirred, added with 0.127 gram of iodine $\left(\mathrm{I}_{2}\right)$, and was stirred again.

\subsection{Production of Carbon Electrodes Coating}

The carbon source was obtained from graphite of $2 \mathrm{~B}$ pencil that was shaded at the thin indium oxide (ITO) conductive part until it got prevalent. After that, glass was burned above a candle flame with a position that the shading faced the flame. The burning was conducted until the burnt covers the surface of the ITO conductive.

\subsection{Creation and Characterization of Solar Cells}

The $\mathrm{TiO}_{2}$ electrodes were created by covering $\mathrm{TiO}_{2}$ paste on ITO glass with an area size of $2 \mathrm{~cm} \times 1$ $\mathrm{cm}$. Then, these two electrodes were drowned in a dye solution for 3 hours. The electrolyte solution was dripped on the $\mathrm{TiO}_{2}$ electrode that had been sensitized with dye and coated with a carbon electrode to be a sandwich structure. Then, the current and voltage of that solar cell were measured using multimeter while illuminated by a 150 -watt halogen lamp. The characterization of the solar cells' manufacturing component includes an analysis using UV-Vis spectrophotometry on the rosella flower's dye extract to identify the maximum wavelength. The SEM and XRD analysis on the produced $\mathrm{TiO}_{2}$ thin film aims to discover the $\mathrm{TiO}_{2}$ morphology and crystal phase.

The characterization of solar cell's components was carried out to reveal the formulated phase using the X-ray diffraction method, while the measurement of dye absorbance value was completed using UV-Vis Lambda 25 spectrophotometer with a light wavelength of 400-700 $\mathrm{nm}$. The X-ray diffraction test used X-Ray Diffractometer (XRD) with a range of diffraction angle $2 \theta\left(20^{\circ}-100^{\circ}\right)$. Scherrer formula was employed to measure the crystallite size of $\mathrm{TiO}_{2}$.

$$
D=\frac{\mathrm{k} \lambda}{\beta \cos \theta}
$$

in which $D$ represents the crystallite size, $\mathrm{k}$ is the constant $(0,94), \lambda$ is Bragg wavelength, $\beta$ is the FWHM (Full-Width Half Maximum) value, and $\theta$ means the Bragg angle.

The electric current and voltage test was carried out using a potentiometer. The electrical circuit schematic in the test is illustrated in Figure 1. The light source used was a 150-watt halogen lamp. The light was directed perpendicular toward the solar cell with a distance variation of $10 \mathrm{~cm}, 20 \mathrm{~cm}$, and $30 \mathrm{~cm}$ from the light source.

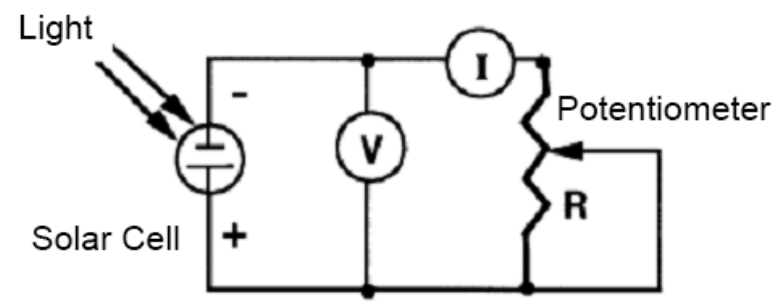

Figure 1. The electrical circuit schematic for the solar cell test. 


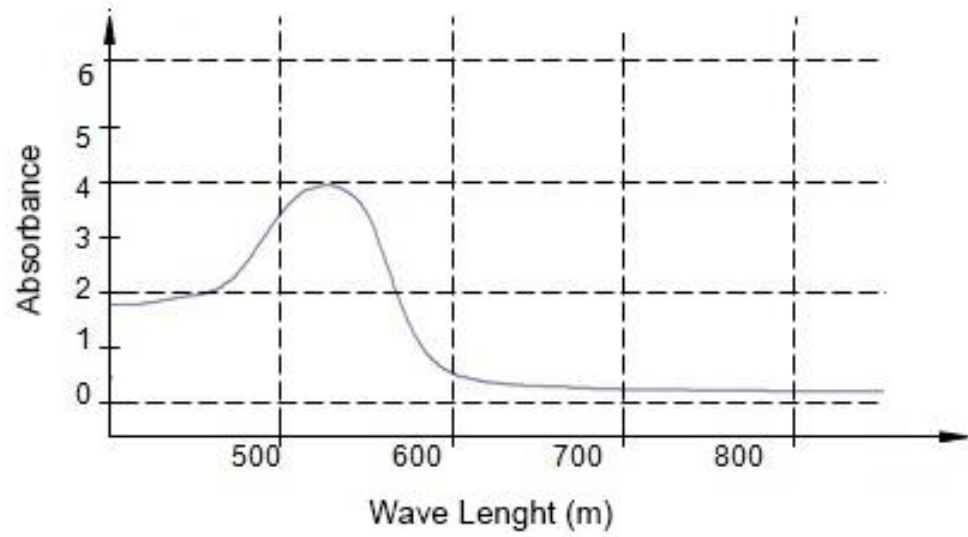

Figure 2. Results of UV-Vis from the rosella flower dye solution.

\section{Results and Discussion}

\subsection{Dye Solution Analysis}

The obtained rosella flower extract was analyzed using UV-Vis spectrophotometry to discover the maximum wavelength of the dye solution. The result of rosella extract UV-Vis spectra is presented in Figure 2. The UV-Vis spectra of the dye solution show that the extract of the rosella flower absorbs photons at the maximum wavelength of $526 \mathrm{~nm}$ with an absorbance value of 3.95. This absorbance value is linear with the results of previous research on the UV spectrum from anthocyanin of mangosteen rind that discovers absorbance at the wavelength of $525 \mathrm{~nm}$ [19]. This result is also supported by another study that measures the spectrum of anthocyanin compound cyanidin group on the castor seed (Ricinus communis) with the maximum absorbance at a wavelength of $522 \mathrm{~nm}$ [20].

The results show that the rosella flower dominantly absorbs the light around $400-550 \mathrm{~nm}$, in line with the redness extract that can be used as a dye in DSSC [19]. The absorbance value is affected by the anthocyanin content on the $\mathrm{TiO}_{2}$ electrode surface. The extraction of the rosella flower produces reddish-purple color with the absorbed color of green and the wavelength of 500-560 nm. The characteristics of dye from this rosella flower are similar to the ruthenium complex N719 type dye with the peak absorbance at a wavelength of $550 \mathrm{~nm}$ and $400 \mathrm{~nm}$. Therefore, the rosella flower dye can be used as an alternative for complex synthetic dye.

\subsection{XRD Analysis of $\mathrm{TiO}_{2}$ Electrodes}

An analysis using X-ray diffraction was carried out to reveal the crystal phase and size that composed the $\mathrm{TiO}_{2}$ thin film. The results of the test are in the form of a diffraction pattern that consists of peaks of $\mathrm{TiO}_{2}$ characteristics, as shown in Figure 3. The obtained diffraction pattern shows a relatively high $\mathrm{TiO}_{2}$ degree of crystallization with sharp peaks and great intensity. The peaks of pure $\mathrm{TiO}_{2}$ characteristics appear at $2 \theta$ angle of $25.38^{\circ} ; 37.85^{\circ} ; 48.10^{\circ}$; and $55.12^{\circ}$, with distance (d) of $3.50 \AA$; $2.37 \AA ; 1.89 \AA$; and $1.66 \AA$.

The obtained diffraction pattern data can be used to know the crystallite size of $\mathrm{TiO}_{2}$ based on the FWHM (Full Width and Half Maximum) value on various peaks using the Scherrer formula. According to the calculation using that formula, the $\mathrm{TiO}_{2}$ crystallite size was obtained. From that calculation, the obtained $\mathrm{TiO}_{2}$ crystallite size is $0.973 \mathrm{~nm}$.

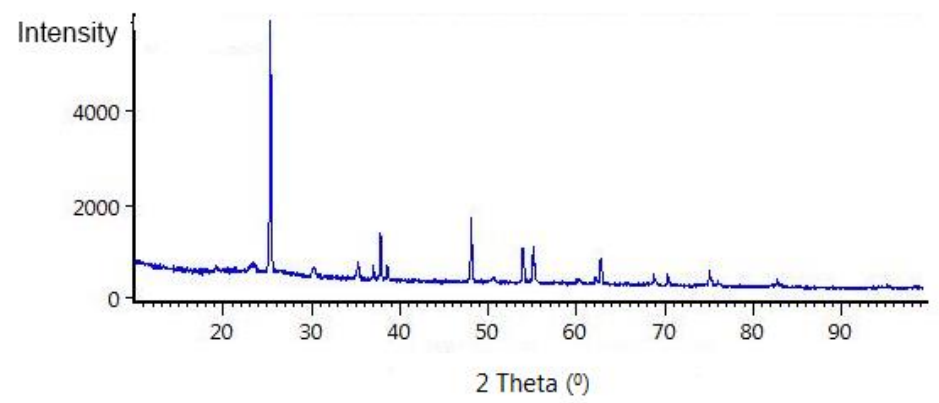

Figure 3. Chart of XRD result of the $\mathrm{TiO}_{2}$ electrode on the ITO glass substrate. 
Table 1. Result of the solar cell's current-voltage measurement using a 150-watt halogen lamp as a light source.

\begin{tabular}{lccccccc}
\hline I-V Characterization & $\begin{array}{c}\mathbf{V}_{\max } \\
(\mathbf{m V})\end{array}$ & $\begin{array}{c}\mathbf{I}_{\max } \\
(\mathbf{m A})\end{array}$ & $\begin{array}{c}\mathbf{P}_{\max } \\
(\mathbf{m W})\end{array}$ & $\begin{array}{c}\mathbf{V}_{\mathbf{o c}} \\
(\mathbf{m V})\end{array}$ & $\begin{array}{c}\mathbf{I}_{\mathbf{s c}} \\
(\mathbf{m A})\end{array}$ & $\mathbf{F F}$ & $\begin{array}{c}\text { Efficiency } \\
(\boldsymbol{\%})\end{array}$ \\
\hline Distance of $10 \mathrm{~cm}$ & 121,7 & 0,08 & 9,736 & 115,8 & 0,07 & 1,201 & 0,162 \\
\hline Distance of $20 \mathrm{~cm}$ & 119,5 & 0,07 & 8,365 & 112,0 & 0,10 & 0,747 & 0,139 \\
\hline Distance of $30 \mathrm{~cm}$ & 117,2 & 0,06 & 7,032 & 123,5 & 0,17 & 0,335 & 0,117 \\
\hline
\end{tabular}

\subsection{Analysis of DSS Performance}

DSSC performance is generated from the measurement of current and voltage using multimeter while being illuminated by a 150 -watt halogen lamp with the distance variation between the lamp and solar cell of $10 \mathrm{~cm}, 20 \mathrm{~cm}$, and 30 with the intensity of 220 lux, 164 lux, and 69 lux, respectively. The results of the I-V DSSC characteristic measurement are shown in Table 1. The current and voltage obtained at $10 \mathrm{~cm}$ distance are more substantial than the ones gained at a distance of $20 \mathrm{~cm}$ and 30 $\mathrm{cm}$. This happens due to the lesser lamp light received at the far distance toward DSSC curtails the produced current value.

In addition, the measured current and voltage value can be used to decide the efficiency of solar cell output. The most exceptional efficiency of $0.162 \%$ is obtained by the closest distance between the lamp and solar cell at $10 \mathrm{~cm}$ with 120 lux intensity. In contrast, the lowest efficiency of $0.117 \%$ is gained by further distance at $30 \mathrm{~cm}$. The efficiency value difference is caused by the amount of light intensity toward the solar cell, a closer distance of light source escalates the light intensity received by the solar cell, so that it generates huge efficiency value. The obtained efficiency value in this study is greater than the previous study $(0.034 \%)$ that used a 24-watt halogen lamp [21]. This is due to the usage of a higher halogen lamp intensity that enables more light absorbed by the dye molecule. Consequently, that accelerates electron transfer on the $\mathrm{TiO}_{2}$ electrode and improves the solar cell performance.

The small current output value of the solar cell (also known as photonic currents) is induced by the coating resistant of the $\mathrm{TiO}_{2}$ electrode layer and the used electrolyte. The enormous resistance value inflicts oxidized electron transfer from dye in $\mathrm{TiO}_{2}$ coating not going well. Thus, the amount of the electrons flowing to the outer circuit getting small. Besides, the function of dye in electron generation and injection to the $\mathrm{TiO}_{2}$ electrode is not yet optimum.

According to the maximum current and voltage value, the solar cell's efficiency is $0.52 \%$. Compare to the solar cell system in another study [12] with an efficiency value of $0.71 \%$, the efficiency of the solar cell in this study is lower. However, this value is improved than another research [14] that uses the FTO substrate with an efficiency of $0.0151 \%$, as well as a study [16] using the TCO substrate with an efficiency of $0.01833 \%$. The usage of the same dye type produces different efficiency values. It is affected by the different characteristics of the rosella flower, from the area where it grows or the means to generate the rosella extract. Besides, there is also a difference in the substrate used as a DSSC supporting component.

\section{Conclusions}

A dye-sensitized solar cell (DSSC) can be generated using a combination of $\mathrm{TiO}_{2}$ inorganic material and organic dye material from the rosella flower. The DSSC from the rosella flower's extract dominantly absorbs light at around 400-550 nm, in line with the redness color of the extract, and can be used as a dye in DSSC. The DSSC performance is affected by the distance of light source used toward the solar cell. The highest efficiency of $0.162 \%$ is obtained by a closer distance between the lamp and solar cell, at $10 \mathrm{~cm}$ with 220 lux intensity. Meanwhile, the lowest efficiency of $0.117 \%$ is achieved at a $30 \mathrm{~cm}$ distance with 69 lux intensity. This different efficiency value is caused by the amount of light intensity toward the solar cell. A closer distance of light source improves the light intensity that accelerates the efficiency value. The features that determine solar cell performance are the structure, dye type (light absorption attribute), and distance between cell to the light source.

\section{References}

[1] K. H. Park et al., "High Performance Dye-Sensitized Solar Cell by Using Porous Polyaniline Nanotube as Counter Electrode," Chem. Eng. J., vol. 260, pp. 393-398, 2015. 
[2] H. M. Upadhyaya et al., "Recent Progress and The Status of Dye-Sensitized Solar Cell (DSSC) Technology with State-of-The-Art Convertion Efficiencies," Sol. Energy Mater. Sol. Cell, vol. 119, pp. 291-295, 2013.

[3] B. O'regan and M. Grätzel, "A Low-Cost, High-Efficiency Solar Cell based on Dye-Sensitized Colloidal $\mathrm{TiO}_{2}$ Films," Nature, vol. 353, no. 6346, pp. 737-740, 1991.

[4] M. Grätzel, "Dye-Sensitized Solar Cells," J. Photochem. Photobiol. C Photochem. Rev., vol. 4, no. 2, pp. 145-153, 2003.

[5] Y. Shi et al., "Solid-State Synthesis of ZnO Nanostructures for Quasi-Solid Dye-Sensitized Solar Cells with High Efficiencies up to 6.46\%," Adv. Mater., vol. 25, no. 32, pp. 4413-4419, 2013.

[6] H. R. An et al., "Improved Photovoltaic Properties of Dye- Sensitized Solar Cells Using Laser Patterned F-Doped $\mathrm{SnO}_{2}$ Thin Films," Arch. Metall. Mater., vol. 60, no. 2, pp. 1241-1245, 2015.

[7] A. A. Khan et al., "Effect of Neodymium on The Photoconversion Efficiency of $\mathrm{TiO}_{2}$ based Dye Sensitized Solar Cells," J. Mater. Sci. Mater. Electron., vol. 26, no. 3, pp. 1737-1742, 2015.

[8] K. N. Li et al., "Macroporous $\mathrm{SnO}_{2}$ Synthesized via A Template-Assisted Reflux Process for Efficient Dye-Sensitized Solar Cells," ACS Appl. Mater. Interfaces, vol. 5, no. 11, pp. 51055111, 2013.

[9] M. R. Narayan, "Review: Dye Sensitized Solar Cells based on Natural Photosensitizers," Renew. Sustain. Energy Rev., vol. 16, no. 1, pp. 208-215, 2012.

[10] R. Suryana, Khoiruddin, and A. Supriyanto, "Beta-carotene Dye of Daucus Carota as Sensitizer on Dye-Sensitized Solar Cell," Mater. Sci. Forum, vol. 737, pp. 15-19, 2013.

[11] H. Bachtiar, N. A. Wibowo, and F. S. Rondonuwu, "Konstruksi Sel Surya Bio Menggunakan Campuran Klorofil-Karotenoid sebagai Sensitizer," JFA (Jurnal Fisika dan Aplikasinya), vol. 11, no. 1, pp. 19-23.

[12] K. Wongcharee, V. Meeyoo, and S. Chavadej, "Dye-Sensitized Solar Cell Using Natural Dyes Extracted from Rosella and Blue Pea Flowers," Sol. Energy Mater. Sol. Cells, vol. 91, no. 7, pp. 566-571, 2007.

[13] L. Okoli et al., "Anthocyanin-Dyed $\mathrm{TiO}_{2}$ Electrode and Its Performance on Dye-Sensitized Solar Cell," Res. J. Recent Sci., vol. 1, pp. 22-27, 2012.

[14] E. A. Adhitya, A. H. Ramelan, and Suharyana "Sintesa Titanium Dioxide $\left(\mathrm{TiO}_{2}\right)$ untuk DyeSensitized Solar Cell dengan Antosianin Bunga Rosela (Hibiscus sabdariffa)," Indo. J. Appl. Phys., vol. 3, no.2, pp. 181-187, 2013.

[15] S. Agustini, "Fabrikasi Dye Sensitized Solar Cell (DSSC) berdasarkan Fraksi Volume $\mathrm{TiO}_{2}$ Anatase-Rutile dengan Gracinia Mangostana dan Rhoeo Spathacea sebagai Dye Fotosensitizer," Jurnal Teknik ITS, vol. 2, no. 2, pp. B131-B136, 2013.

[16] Mustaqim, A. Haris, and Gunawan, "Fabrikasi Dye-Sensitized Solar Cell Menggunakan Fotosensitizer Ekstrak Bunga Rosela (Hibiscus sabdariffa L) dan Elektrolit Padat Berbasis PEG (Polyethylene Glycol),” J. Kim. Sains Apl., vol. 20, no. 2, pp. 62-67, 2017.

[17] Mardiah, L. Amalia, and Agus Sulaeman, "Ekstraksi Kulit Batang Rosella (Hibiscus Sabdariffa L.) sebagai Pewarna Merah Alami," J. Pertanian, vol 1, no. 1, pp. 1-8, 2010.

[18] A. H. Yuwono et al., "Sel Surya Tersentisasi Zat Pewarna Berbasis Nanopartikel TiO2 hasil Proses Sol Gel Perlakuan Pasca Hidrotermal," Jurnal Material dan Energi Indonesia, vol. 3, no. 1, pp. 127-140, 2011.

[19] W. Supiyanti, E. D. Wulansari, and L. Kusmita, "Uji Aktivitas Antioksidan dan Penentuan Kandungan Antosianin Total Kulit Buah Manggis (Garcinia Mangostana L.)," Majalah Obat Tradisional, vol. 15, no 2, pp. 64-70, 2010.

[20] J. M. Bueno et al., "Analysis and Antioxidant Capacity on Anthocyanin Pigments. Part II: Chemical Structure, Color, and Intake of Anthocyanins," Critical Rev. in Analytical Chemistry, vol. 42, no. 2, pp. 126-151, 2012.

[21] A. Maddu, M. Zuhri, and Irmansyah, "Penggunaan Ekstrak Antosianin Kol Merah sebagai Fotosentizer Pada Sel Surya $\mathrm{TiO}_{2}$ Nanokristal Tersentisasi Dye," Makara, vol. 11, no. 2, pp. 78-84, 2007. 